\title{
Teen Marriage and Feeding Behaviour to Children in Indonesia
}

\author{
Indriyatia \\ Dwini Handayani ${ }^{b}$ \\ Universitas Indonesia
}

\begin{abstract}
One of the key determinants of child nutritional status during the critical window period (the first thousand days of life) is feeding practices, including exclusive breastfeeding, continued breastfeeding, and complementary feeding. The condition of mother, as the main child caretaker, will determine the child's nutritional status and nutrition patterns. This research will focus on the effect of teen marriage age, which will be predicted through education, on infant and young child feeding behaviour. Previous studies mainly focussed on only one type of child feeding, but this study discusses three types of child feeding behaviour. This study uses the Indonesian Demographic and Health Survey data in 2012 and the method of analysis is binary logistic regression. The sample for this study is based on 4,177 married women from age 15 to 49 who currently has a first child aged 0 to 23 months. The result shows that mothers who married early and with lowest education attainment have a better behaviour of exclusive and continued breastfeeding, but the worst on complementary feeding.
\end{abstract}

Keywords: Child feeding behaviour, complementary feeding, continued breastfeeding, exclusive breastfeeding, teen marriage

JEL classification: I12, J12, 015

\section{Introduction}

Child malnutrition keeps being the main health problem and is the largest mortality cause in many developing countries (Müller \& Krawinkel, 2005). This phenomenon is the beginning of declining physical and intellectual productivity in adulthood (Gillespie \& Haddad, 2001 in Smith, Ramakrishnan, Ndiaye, Haddad, \& Martorell, 2003). The first two years, as the beginning of life, is the most crucial development phase, so that the nutrition condition of the child at that time is the most important part in forming qualified human beings. ${ }^{1}$ The investment during the two years in the beginning of life, by ensuring that the feeding practice is carried out optimally, may prevent and reduce lack of nutrition in children that will disrupt the basis of life development (Gupta, 2006).

a Faculty of Economics and Business, Universitas Indonesia, Jl. Prof. Dr. Sumitro Djojohadikusumo, Kukusan, Beji, Kota Depok, Jawa Barat 16424, Indonesia. Email: indy_suha@yahoo.com (Corresponding author)

b Faculty of Economics and Business, Universitas Indonesia, Jl. Prof. Dr. Sumitro Djojohadikusumo, Kukusan, Beji, Kota Depok, Jawa Barat 16424, Indonesia. Email: dwini.handayani11@ui.ac.id, dwiniarianto@yahoo. com

1 The period from conception until two years old (the first thousand days of life) has been identified as the most critical window of opportunity for preventing under nutrition (Prendergast \& Humphrey, 2014; Leroy, Ruel, Habicht, \& Frongillo, 2014).

Article Info: Received 11 October 2017; Revised 20 Apr 2018; Accepted 20 July 2018

https://doi.org/10.22452/MJES.vol55no2.1 
Previous researches mention that stunting is an indicator of malnutrition, which caused short term or long term impacts, and causes 35 percent of child mortality throughout the world (Prüss-Üstün, Bos, Gore, \& Bartram, 2008). Based on the result of the Indonesian Basic Health Research, the prevalence of stunting in Indonesia tended to increase from 2007 until 2013. In fact, based on data of the United Nations Development Programme (UNDP) of 2014, Indonesia is included as one of the countries with the highest stunting prevalence in the Southeast Asian region.

The nutrition status of children aged 0-23 months is directly affected by the feeding practice and occurrence of infection (Smith et al., 2003). This is the basis why nutrition intervention should focus on the mother, pregnancy and breastfeeding period until the child reach the age of two years old (Hoddinott, Alderman, Behrman, Haddad, \& Horton, 2013). The optimal breastfeeding practice is an effective prevention that may reduce child mortality by three to sixteen percent, while the provision of adequate complementary food may prevent child mortality to six percent (Gupta, 2006). Roche et al. (2017) conducted a research in Ecuador and discovered that the optimal breastfeeding practice and improvement of nutritious local food have the potential to reduce the stunting case of children.

The Indonesian Demography and Health Survey from 1994 until 2012 showed that the percentage of exclusive breastfeeding is still fluctuating and is still far from the government determined target of 80 percent (Briawan, 2004), while children aged 6-23 months who have obtained complementary food in accordance with the recommendation of the World Health Organization (WHO) is only around 37 percent (BPS et al., 2013). In view of the importance of feeding (nutrition) children as the beginning of forming human capital, the government needs to make efforts and provide support to improve the percentage of breastfeeding and complementary feeding in accordance with WHO recommendations.

\section{Conceptual Framework}

The practice of poor breastfeeding and complementary feeding, in addition to the high level of infectious diseases, are the main causes of malnutrition during the first two years of life (UNICEF, 1998). WHO (2003a) represented that the direct consequences of malnutrition during this period include morbidity, mortality as well as delay of mental and motor development. In the long term, malnutrition may cause interruption of intellectual performance, working capacity, reproduction and health results on the overall during the adolescence period and adulthood. As such, the cycle of malnutrition will keep ongoing. Women who in the beginning of life experienced malnutrition will have greater possibility to give birth to an infant with malnutrition or with low weight.

In the framework of reducing illness and mortality rate of children, UNICEF and WHO recommended that feeding of infants and children be optimally carried out. The optimal feeding of infant and toddlers is intended to ensure that each child obtains the best beginning of life through exclusive breastfeeding during the first six months, continued breastfeeding during two or more years and it should also be completed with a proper, correct and adequate complementary feeding after six months (WHO, 2003b). 


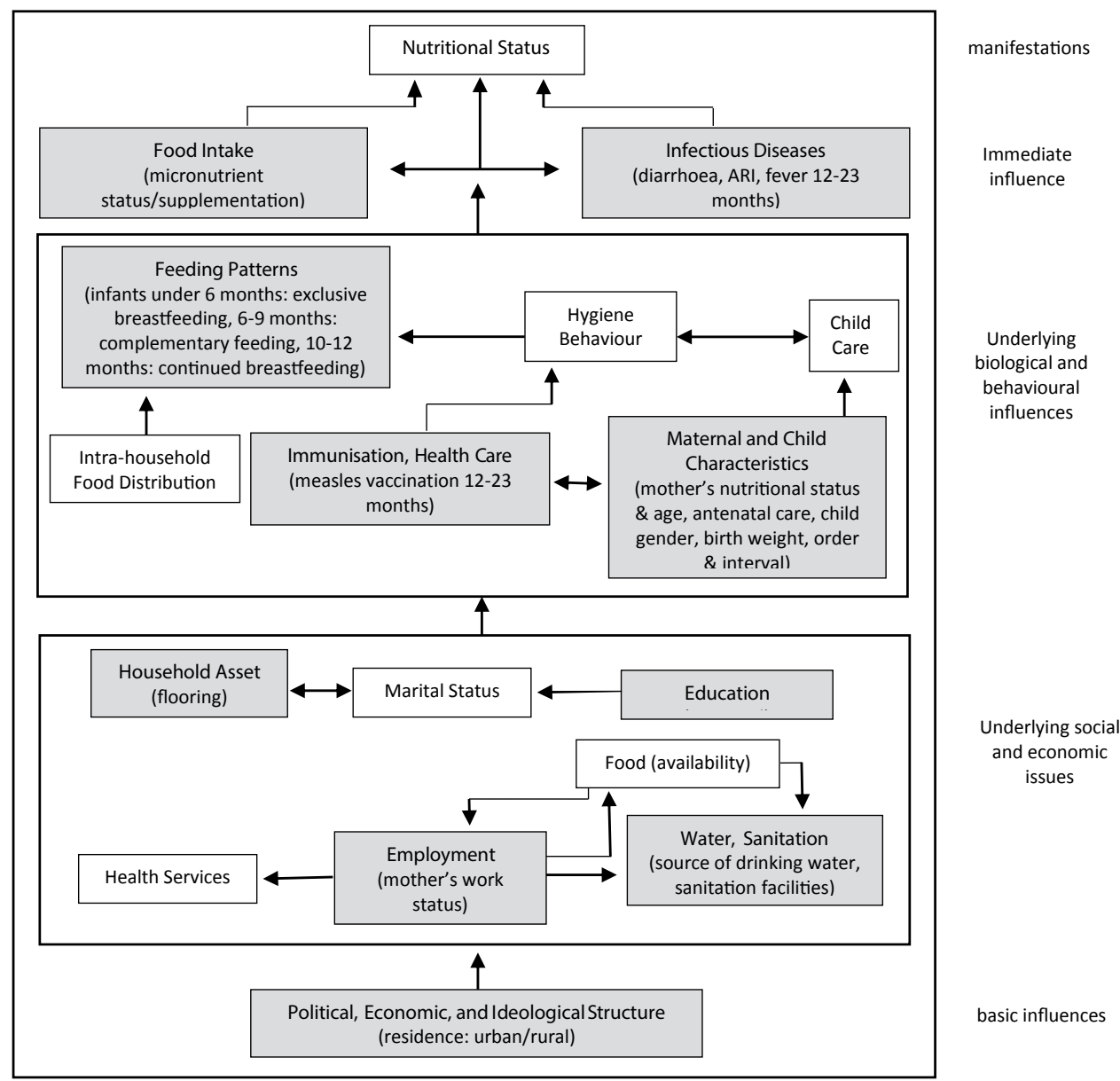

Figure 1. Conceptual framework for the child nutritional status Source: UNICEF, 1998.

Breastfeeding is a biological process of all mammals but in human beings this process is affected by certain social factors (Stolzer, 2005; Cornall, 2011). The optimal breastfeeding process includes the initiation during one hour of the beginning of life, exclusive breastfeeding for the first six months, and continued breastfeeding until the infant reaches the age of 2 years or more (WHO, 2003b). WHO defined exclusive breastfeeding as the practice of only breastfeeding the infant during the first six months of life (there is no other food or liquid except oral rehydration salt, vitamins, minerals, and drugs).

Complementary food is defined as the beginning of the process when only breastfeeding is no longer adequate to comply with the nutrition needs of infants aged 6-23 months. Other food and liquid are needed simultaneously along with breastfeeding. In case infants at this age do not obtain other intakes in addition to 
breastfeeding, then their growth may possibly be delayed. WHO provided several indicators related to complementary food, among others is the minimum diversity diet that is used in this research as proxy of adequate food micronutrient density. Infants aged 6-23 months are considered eating adequately if they obtain 4 groups of food or more from the 7 food groups ${ }^{2}$ (WHO, 2010). Data in 10 developing countries shows that children at the age of 6-23 months who consume a minimum 4 groups of food have the possibility to consume staple food, at least one animal and one fruit or one vegetable (WHO, 2010).

The biological dimension and fertility behaviour of human beings are connected through a series of determinant factors, namely the first marriage age (Bongaarts, 1983). The first marriage age may become the indicator when a woman has the possibility to become pregnant and to give birth (Yuniarti, Sukandar, \& Susiarno, 2013). The first marriage age in Indonesia is an important matter in fertility, since according to religious and social norms, child birth should occur after marriage (Restyani, 2001). Restyani also informed that in general a newly married husband and wife tend to have a child soon. This is in line with what was informed by Becker (1973), namely that the main objective of a marriage and a family is to have children and raise them. As such, the model of first marriage age for women may be applied at the model of first child birth age (Shirahase, 2000 in McDonald, 2013). A marriage is called an early marriage when it is conducted before a girl is physically, physiologically and psychologically ready to take the responsibility of marriage and having children (Walker, 2012). Marriage at an early age has a negative relationship with socio-economic aspects such as low education level, low income and low asset accumulation, thus impacting on the health of the mother, particularly at the time of giving birth, and also on the health of the infant and child (Sukamdi, Yuarsi, \& Tamtiari, 1995; Martino, Collins, \& Ellickson, 2004).

Previous studies showed that women with high education tend to postpone their marriage (Bogue, 1969 in Graff, 1979). Glewwe (1999) in Azeze and Huang (2014) has the opinion that there are three formal education mechanism possibilities that affect the knowledge of mothers on health. First, the prospective mother directly obtains health knowledge from the formal school. Second, reading and arithmetic skills obtained at school assist the prospective mother in diagnosing and medicating child health problems. Third, exposure of the modern community through formal school made women accept modern medical care more easily. Mother's knowledge on nutrition has an important role in determining the lack of nutrition in children (Christiansen \& Alderman, 2004 in Azeze \& Huang, 2014).

This research intends to look at the impact of age at first marriage, as the indicator when a woman begins to become a mother, on the behaviour of providing nutrition to the child aged 0-23 months, covering the practice of exclusive breastfeeding, continued breastfeeding until the age of two years and complementary feeding commencing aged 6 months. Mothers who married at an older age and have higher education levels are

2 The 7 food groups are: 1. grains, roots and tubers, 2. legumes and nuts, 3. dairy products (milk, yogurt, cheese), 4. flesh foods (meat, fish, poultry and liver/organ meats), 5. eggs, 6. vitamin-A rich fruits and vegetables, and 7 . other fruits and vegetables. 
expected to have an adequate knowledge on child health and nutrition, so that the behaviour of providing nutrition to the child becomes better.

\section{Research Methodology}

This research uses data from the Indonesian Demography and Health Survey (Survei Demografi dan Kesehatan Indonesia - SDKI) results of 2012 (Badan Pusat StatistikBPS (Statistics Indonesia), National Population and Family Planning Board (BKKBN), Kementerian Kesehatan (Kemenkes-MOH), \& ICF International, 2013). SDKI was carried out in 33 provinces throughout Indonesia, providing detailed information on population, family planning and health. The sample unit for analysis, consisting of 4,177 women, are those at the aged of 15-49 who were ever married and has a first child, living with the mother and at the age of 0-23 months. For the logistic regression, three types of behaviour are studied, i.e. exclusive breastfeeding behaviour, continued breastfeeding behaviour and provision of complementary food breastfeeding. For these 3 logistic regressions, the sample is divided into two groups. The first group, amounting to 907 women, is to examine breastfeeding behaviour for the sample who has first children aged 0-5 months old. The second group, consisting the balance of 3,270 women, is to examine continued breastfeeding and also provision of complementary food behaviour for those whose first child is aged 6-23 months.

The analysis framework below shows that there are various factors affecting the behaviour of providing nutrition to children aged 0-23 months, one of those is the age at first marriage. However, because the age at first marriage is presumed to be experiencing some endogenous problem, it is necessary to make some adjustments.

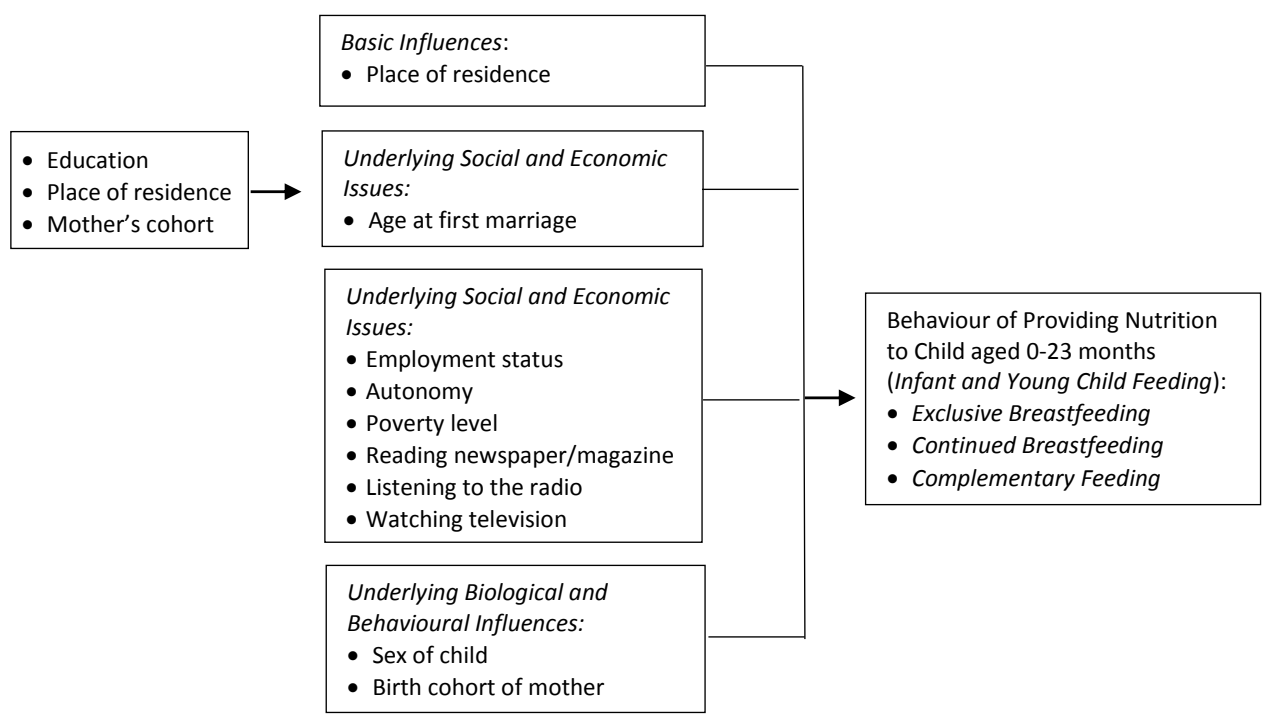

Figure 2. Analysis framework 
The adjustment uses the OLS (Ordinary Least Square) as shown in Equation 1, so that the result is more consistent and is able to minimise errors. The predicted age at first marriage $\left(\mathrm{AFM}_{\text {hat }}\right)$ is used as independent variable to estimate the behaviour of providing nutrition to children aged 0-23 months, jointly with the other control variables, by using the binary logistic regression analysis technique. There are three types of behaviour in providing nutrition to children aged 0-23 months, namely exclusive breastfeeding, continued breastfeeding, and complementary feeding.

$$
\begin{aligned}
\text { AFM }_{\text {hat }}=\alpha_{0}+ & \alpha_{1} \text { EDUCATION }+\alpha_{2} \text { RESIDENCE }+\alpha_{3} \text { COHORT }+\mu \\
\operatorname{In}\left(\frac{p_{1 i}}{1-P_{1 i}}\right)= & \beta_{0 i}+\beta_{1 i} \text { AFM }_{\text {hat }}+\beta_{2 i} \text { RESIDENCE }+\beta_{3 i} \text { WORK }+\beta_{4 i} \text { AUTONOMY }+ \\
& \beta_{5 i} \text { POVERTY }+\beta_{6 i} \text { RADIO }+\beta_{7 i} \text { NEWSPAPER }+\beta_{8 i} \text { TV }+ \\
& \beta_{9 i} \text { COHORT }+\beta_{10 i} \text { SEXCHILD }
\end{aligned}
$$

where $P_{1 i}$ is the opportunity of occurrence of the three types of feeding behaviour to children (i.e. exclusive breastfeeding, continued breastfeeding and complementary feeding). $A F M_{\text {hat }}$ is the age at first marriage as the predicted result of Equation 1. RESIDENCE is the residential area of women, either urban or rural. WORK is the working status of women. AUTONOMY describes the engagement of women in managing the household income. POVERTY is the household poverty status. RADIO describes the exposure to radio at least once a week. NEWSPAPER is reading the newspaper/ magazine at least once a week. TV describes the exposure to television at least once a week. COHORT is the birth cohort of the mother, consisting of the cohort of 1963-1977, 1978-1987 and 1988-1997 (as the reference categories). SEXCHILD is the gender of the first child that is observed. EDUCATION describes years of schooling of the mother.

\section{Result and Analysis}

Based on the analysis shown in Figure 3, the majority of children below the age of six months do not obtain exclusive breastfeeding, while most children aged 6-23 months still obtain adequate breastfeeding and complementary food. This shows that women with children below the age of two years already have sufficient awareness to breastfeed their children, even though they do not give exclusive breastfeeding.

\subsection{Age of First Marriage}

Results in Table 1 show that years of schooling (education), place of residence and birth cohort significantly influence age of first marriage. The regression shows that years of schooling is the main variable that determines the age of first marriage (AFM). The higher a woman's education then the higher their first age of marriage. Previous studies also described that education is a strong and significant variable that influence a woman's age of first marriage (Jones, 2001 ). The findings also show that women living in urban areas has a higher age of first marriage that those living in rural areas. In Jones 


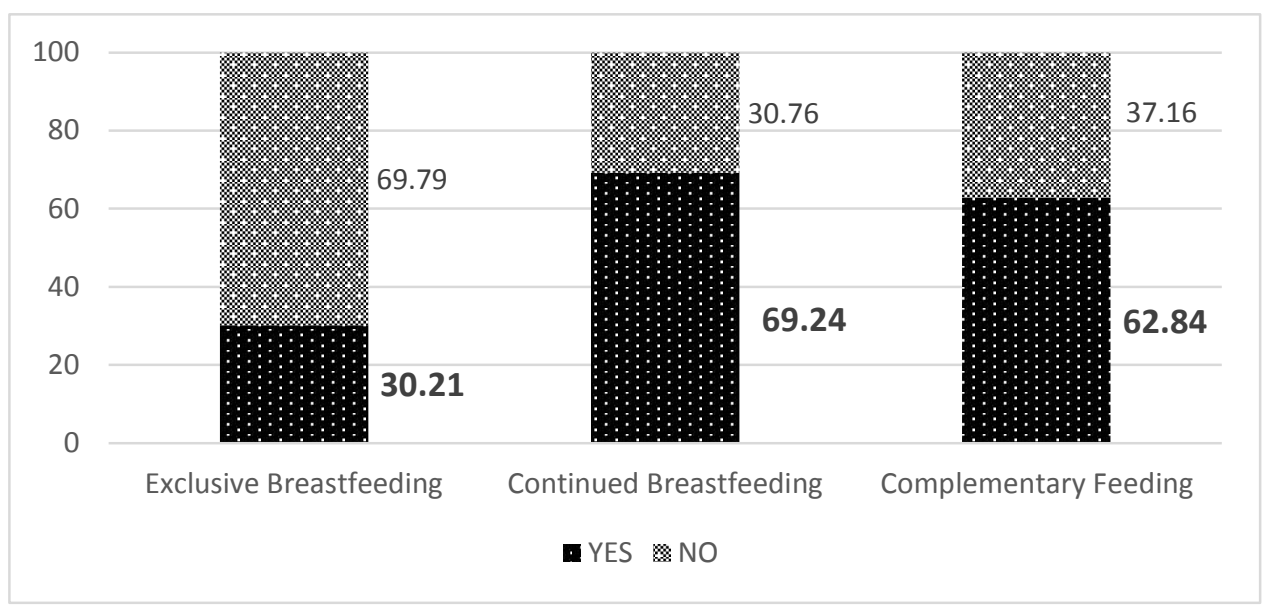

Figure 3. Provision of exclusive breastfeeding, continued breastfeeding and complementary breastfeeding (percentage) Source: SDKI 2012 (processed).

Table 1. Age of first marriage regression

\begin{tabular}{lc}
\hline Covariate & Coefficient (B) \\
\hline Total observations & 4177 \\
Intercept & $14.323^{* * *}$ \\
Education & $0.451^{* * *}$ \\
Residence (0 = Rural) & \\
$\quad$ Urban & $0.292^{* *}$ \\
Birth cohort of mother $(0=1988-1997)$ & \\
$\quad$ 1963-1977 & $3.266^{* * *}$ \\
$\quad 1978-1987$ & $2.426 * * *$ \\
\hline
\end{tabular}

Note: $\quad * * * p<0.01, * * p<0.05, * p<0.1$.

Source: SDKI 2012 (processed).

and Gubhaju (2008), they stated that the increase of first age of marriage in Indonesia is a result from increase in educational attainment and urbanisation. Urbanisation has also widen the accessibility to education and other economic activities that will also increase the first age of marriage. Birth cohort of women shows that the younger their cohort, women tend to not delay their marriage. This finding, in line with Romdoniah (2016) and Lestariningsih (2016), explains that most of the women from the younger cohort are still single. Thus, the data only calculates the age of first marriage of women who marry early. 


\subsection{Behaviour of Exclusive Breastfeeding}

Table 2 shows that the variables which statistically affect the behaviour of exclusive breastfeeding are age at first marriage, working status, exposure to radio and gender of child. The age at first marriage is the main variable in this research, which is significantly affected by the mother's years of schooling, place of residence and birth cohort. It is identified from the regression result of Equation 1 that the increase in years of schooling will increase the age at first marriage, and as such, women who married at an older age and with higher education have a lower probability to provide exclusive breastfeeding to their children. Kumwenda et al. (2015) discovered the existing negative relationship between education and age of mothers and breastfeeding activity in Malawi. As developing countries, Indonesia and Malawi have similar relationship patterns between age and education of mothers and breastfeeding activity. According to this study, mothers with high education tend to be working, so that they do not have time to breastfeed their children. However, a different result is found in developed countries, which also indicates that there is a positive relationship between the age and education of mothers and breastfeeding activity (Dubois \& Girard, 2003; Odom, Li, Scanlon, Perrine, \& Grummer-Strawn, 2014; Radwan, 2013).

The working status of mothers also significantly affects the exclusive breastfeeding practice to children aged 0-5 months. What is interesting is that working mothers evidently have a higher probability to provide exclusive breastfeeding compared to unemployed mothers. Breastfeeding is a natural process, and its success does not need special equipment and high costs but needs patience, time and knowledge on breastfeeding and environmental support (Rusli, 2010 in Kusumawati, 2014). Mothers within a community that provides good support to the breastfeeding practice tend to breastfeed their infants (Loiselle, Semenic, Côté, Lapointe, \& Gendron, 2001). Working mothers usually have an environment and community as places to share information and to mutually support each other on certain matters, including breastfeeding activity, either from colleagues or others. In addition, working women using their resources are able to access the media and to buy the needs to support their exclusive breastfeeding activity.

Exposure to the media, namely radio, newspaper/magazine or television, is used as measurement of external environmental impacts toward the pattern of providing nutrition to children. The media that provides a significant impact to exclusive breastfeeding practice is exposure to radio. It means that mothers who listen to the radio at least once a week have a higher probability to provide exclusive breastfeeding compared to mothers who are not exposed to the radio or exposed to the radio less than once a week. This finding is in line with a study conducted by Dhakal, Lee and Nam (2017) who argued that exposure to the radio is one of the key variables for the success of breastfeeding practice in Congo. In many developing countries, radio is used to spread information and knowledge on health and is presumed as being able to improve the community health (Acharya et al., 2015 in Dhakal et al., 2017).

Another variable that significantly affects exclusive breastfeeding practice is gender of the child. It means that gender difference of children will provide different impacts on the behaviour of exclusive breastfeeding. Male infants aged 0-5 months 
Table 2. Binary logistic regression result of mother's feeding behaviour to children aged 0-23 months

\begin{tabular}{|c|c|c|c|}
\hline \multirow[b]{2}{*}{ Covariate } & \multicolumn{3}{|c|}{$\operatorname{Exp}(B)$} \\
\hline & $\begin{array}{c}\text { Exclusive } \\
\text { breastfeeding }\end{array}$ & $\begin{array}{c}\text { Continued } \\
\text { breastfeeding }\end{array}$ & $\begin{array}{c}\text { Complementary } \\
\text { breastfeeding }\end{array}$ \\
\hline (1) & $(2)$ & (3) & (4) \\
\hline Total observations & 907 & 3,270 & 3,270 \\
\hline Intercept & 21.453 & 36.722 & 0.063 \\
\hline \multicolumn{4}{|l|}{ Basic Influences } \\
\hline Place of residence ( 1 = City) & $\begin{array}{c}0.860 \\
(0.172)\end{array}$ & $\begin{array}{l}0.751^{* * * *} \\
(0.087)\end{array}$ & $\begin{array}{l}1.370 * * * \\
(0.085)\end{array}$ \\
\hline \multicolumn{4}{|l|}{ Underlying Social and Economic Issues } \\
\hline Predicted AFM (age at first marriage) & $\begin{array}{l}0.805^{* * *} \\
(0.050)\end{array}$ & $\begin{array}{l}0.868^{* * *} \\
(0.026)\end{array}$ & $\begin{array}{l}1.137^{* * *} \\
(0.025)\end{array}$ \\
\hline Working status ( 1 = Working) & $\begin{array}{c}1.334^{*} \\
(0.166)\end{array}$ & $\begin{array}{l}0.676^{* * *} \\
(0.081)\end{array}$ & $\begin{array}{l}1.232^{* *} \\
(0.079)\end{array}$ \\
\hline Autonomy ( 1 = Having the role) & $\begin{array}{l}1.033 \\
(0.234)\end{array}$ & $\begin{array}{c}1.230^{*} \\
(0.118)\end{array}$ & $\begin{array}{l}1.037 \\
(0.115)\end{array}$ \\
\hline Poverty status ( 1 = Not poor $)$ & $\begin{array}{c}0.993 \\
(0.177)\end{array}$ & $\begin{array}{c}0.917 \\
(0.092)\end{array}$ & $\begin{array}{l}1.333^{* * *} \\
(0.087)\end{array}$ \\
\hline Radio (1 = Listening) & $\begin{array}{l}1.817^{* *} \\
(0.200)\end{array}$ & $\begin{array}{l}1.404^{* *} \\
(0.110)\end{array}$ & $\begin{array}{l}1.451^{* * *} \\
(0.110)\end{array}$ \\
\hline Newspaper/Magazine (1 = Reading) & $\begin{array}{c}0.885 \\
(0.262)\end{array}$ & $\begin{array}{l}0.769 * * \\
(0.121)\end{array}$ & $\begin{array}{l}1.406^{* *} \\
(0.140)\end{array}$ \\
\hline Television (1 = Watching) & $\begin{array}{l}1.176 \\
(0.207)\end{array}$ & $\begin{array}{c}1.044 \\
(0.113)\end{array}$ & $\begin{array}{l}1.393^{* * *} \\
(0.102)\end{array}$ \\
\hline \multicolumn{4}{|l|}{$\begin{array}{l}\text { Underlying Biological and } \\
\text { Behavioural Influences }\end{array}$} \\
\hline \multicolumn{4}{|l|}{ Birth cohort of mother $(0=1988-1997)$} \\
\hline 1963-1977 & $\begin{array}{c}1.292 \\
(0.258)\end{array}$ & $\begin{array}{l}1.675^{* * *} \\
(0.136)\end{array}$ & $\begin{array}{l}0.760^{* *} \\
(0.128)\end{array}$ \\
\hline 1978-1987 & $\begin{array}{c}0.997 \\
(0.199)\end{array}$ & $\begin{array}{l}1.514^{* * *} \\
(0.111)\end{array}$ & $\begin{array}{r}0.828^{*} \\
(0.104)\end{array}$ \\
\hline Sex of child ( 1 = Male) & $\begin{array}{l}1.328^{*} \\
(0.150)\end{array}$ & $\begin{array}{c}0.921 \\
(0.078)\end{array}$ & $\begin{array}{c}1.119 \\
(0.075)\end{array}$ \\
\hline
\end{tabular}

Note: $\quad * * * \mathrm{p}<0.01,{ }^{* *} \mathrm{p}<0.05, * \mathrm{p}<0.1$.

Source: SDKI 2012 (processed). 
have a higher probability to obtain exclusive breastfeeding compared to female infants. Male infants in Saudi Arabia, a country with majority Moslem population, have a higher probability to obtain exclusive breastfeeding compared to female infants (Radwan, 2013).

\subsection{Behaviour of Continued Breastfeeding}

Variables that significantly affect continued breastfeeding practice are age at first marriage, place of residence, working status, autonomy, radio exposure, newspaper/ magazine exposure, and cohort of the mother. Similar to exclusive breastfeeding, age at first marriage significantly affects the behaviour of continued breastfeeding to children aged 6-23 months. This variable provides the strongest impact among the other independent variables that are used in the model. The difference in age at first marriage of a woman will provide different impacts on continued breastfeeding practice to the child aged 6-23 months. Women who married at an older age have a lower probability of providing continued breastfeeding to their children aged 6-23 months.

Previous theories stated that a higher age at first marriage gave women the opportunity to be longer at school (Freedman, 2009). As such, it is expected that through higher education knowledge on health, including knowledge on breastfeeding, will also be higher. A higher level of knowledge will develop a behaviour that is more concerned towards breastfeeding activity (Dhakal et al., 2017). However, this study finds that age at first marriage has a significant negative relationship toward continued breastfeeding activity. This is possible since women who married at an older age and have higher education have higher possibilities for work outside the home (Naanyu, 2008). Rippeyoung and Noonan (2012) argued that breastfeeding is in the opportunity cost of mothers' time, because "the need to feed an infant often precludes the mother's engaging in a variety of other activities."

The working status of mothers significantly affects continued breastfeeding practice to children aged 6-23 months. Different from the results of exclusive breastfeeding, the working status of mothers has a negative relationship with continued breastfeeding activity. Working mothers have a lower probability of providing continued breastfeeding compared to unemployed mothers. This finding is in line with a study conducted by Radwan (2013) in Saudi Arabia who discovered that unemployed mothers have higher opportunity to provide breastfeeding compared to working mothers. This is possible since working mothers have limited time to take care of their children. The different impact of working mothers with respect to exclusive breastfeeding and continued breastfeeding is possible due to the lack of concern (awareness) of working mothers towards continued breastfeeding after six months.

The autonomy variable that is used in this research describes the engagement of women in managing household income, either that originating from the wife, husband or both. Women who have low control on household resources are related to the low nutrition status of the children (Smith et al., 2003). Statistically, the autonomy of women significantly affects continued breastfeeding to children aged 6-23 months. It means that mothers with autonomy in managing household income have a higher tendency to provide continued breastfeeding compared to mothers without autonomy. 
Place of residence of mothers, which describes the economic, political, ideological and cultural conditions, significantly affects continued breastfeeding of children aged 6-23 months. Mothers who live in urban areas have a lower probability of providing continued breastfeeding compared to mothers who live in rural areas. However, Nguyen (2014) discovered differently, where mothers in Vietnam who live in the city have a higher opportunity to provide breastfeeding (early breastfeeding) compared to mothers who live in the village. Nguyen informed that existing globalisation and urbanisation have increased the gap between urban and rural areas in regard to the provision of facilities that support breastfeeding activity.

Exposure to the media has theoretically been proven to provide opportunity to obtain better information and knowledge. Better knowledge, particularly with regard to breastfeeding, will affect the behaviour of mothers to be more concerned toward breastfeeding activity for their children (Dhakal et al., 2017). The media that provides significant impacts and has a positive relationship with continued breastfeeding is exposure to the radio. It means that mothers who listen to the radio at least once a week have a higher probability to provide continued breastfeeding compared to mothers who are not exposed to the radio or are exposed to the radio less than once a week. Meanwhile, exposure to newspapers/magazines provides significant impacts with a negative direction to continued breastfeeding activity. The probability of mothers providing continued breastfeeding to their children aged 6-23 months is lower for mothers who read newspapes/magazines at least once a week than for mothers who are not exposed to newspapers/magazines or are exposed to the newspapers/ magazines of only less than once a week.

Hamilton and Lewis (2014) conducted a study in the United States in order to observe impacts of media exposure, particularly newspapers/magazines, toward breastfeeding activity. This study discovered that, unlike the theory that argues that the media can support breastfeeding activity, newspapers published in the United States do not support breastfeeding activity. This is because newspapers in the United States seldom contain articles with regard to breastfeeding activity. A similar situation may possibly also occur in Indonesia, namely that newspapers/magazines seldom contain articles on breastfeeding activity. Another possibility which may occur is that women prefer to find information on breastfeeding through the Internet media (data is not available in SDKI of 2012).

Birth cohort of the mother provides a significant impact and has a positive direction for continued breastfeeding practice. It means that a different birth cohort of a mother will provide different impacts to continued breastfeeding practice to her child aged more than six months. Mothers who were born in the birth cohort of 1963-1977 have 1.7 times higher probability of continued breastfeeding compared to mothers who were born in the birth cohort of 1988-1997. Meanwhile, mothers who were born in the birth cohort of 1978-1987 have a higher probability of 1.5 times compared to mothers who were born in the birth cohort of 1988-1997. In other words, mothers who were born in the oldest birth cohort (1963-1977) have the highest probability on continued breastfeeding to children aged 6-23 months. This matter should require attention, as it is shown that the probability of continued breastfeeding to children aged 6-23 months from mothers who come from the younger generation keeps decreasing. 


\subsection{Behaviour of Providing Complementary Feeding}

The behaviour of providing complementary feeding to children aged 6-23 months are significantly affected by age at first marriage, place of residence, working status, poverty status, exposure to media (radio, newspapers/magazines and television), and birth cohort of the mother. Age at first marriage significantly affects complementary feeding to children aged 6-23 months. Women who married for the first time at an older age have a higher probability to provide complementary feeding in accordance to what is recommended for children aged 6-23 months. This finding is in line with the theory of a study conducted by Victor, Baines, Agho and Dibley (2014) in Tanzania, who discovered that age at first marriage of the mother has a positive impact on complementary feeding to infants aged 6-23 months. An older age of marriage with a higher education level enables women to enter the job market. Working mothers certainly have better resources to comply with the needs of family members, including providing complementary food for children aged 6-23 months.

The working status of mothers significantly affects complementary feeding to children aged 6-23 months. Working mothers have a higher probability to provide complementary feeding in accordance with the WHO recommendation compared to mothers who are unemployed. Victor et al. (2014) also discovered that the working status of mothers also has significant impacts on complementary feeding to infants aged 6-23 months but does not have a significant relationship with the frequency of complementary breastfeeding in Tanzania. Working mothers tend to have more resources that enable the provision of complementary feeding to children with the recommended variety.

The poverty level variable that is used in this research describes the household economic status. The poverty level variable significantly affects complementary feeding practice. Mothers from non-poor households have a higher probability to provide complementary feeding in accordance with the recommendation of WHO to children aged 6-23 months compared to mothers from poor households. The study in Tanzania discovered that the household poverty status of the mother has significant impacts on complementary feeding to infants aged 6-23 months (Victor et al., 2014). The household economic condition has impacts on the ability of the household, particularly the parents, to comply with the needs of their children. Mothers from poor or nonprosperous households have limitations with regard to their options, including providing complementary feeding to children in accordance with the recommendation.

The place of residence of mothers describes the environmental condition viewed from the economic, political, ideological or cultural aspects. This variable significantly affects the complementary feeding practice to children aged 6-23 months. It means that mothers who live in an urban area have a higher probability to provide complementary feeding in accordance with the WHO recommendation compared to mothers who live in the rural area. The place of residence of mothers has a significant positive impact on complementary feeding to infants aged 6-23 months in Tanzania (Victor et al., 2014). Mothers who live in the urban area obtain facilities to access information and knowledge on complementary breastfeeding, simultaneously with regard to options on the variety of complementary breastfeeding. 
This study shows that exposure to the media, namely radio, newspapers/ magazines or television has impacts on the provision of food to children aged 0-23 months. All media (radio, newspapers/magazines and television) provide significant impacts and with positive direction to complementary feeding practice. This finding shows that mothers who listen to the radio at least once a week have a higher probability to provide complementary feeding in accordance with the WHO recommendation compared to mothers who are not exposed to the radio or are exposed to the radio less than once a week. Likewise, mothers who read the newspapers/ magazines at least once a week have a higher probability to provide complementary feeding in accordance with the WHO recommendation compared to mothers who are not exposed to newspapers/magazines or are exposed to the newspapers/magazines less than once a week. This is similar to mothers who watch the television at least once a week, who have a higher probability of providing complementary feeding in accordance with the WHO recommendation compared to mothers who do not watch television or watch television less than once a week. This finding is in line with the study conducted by Victor et al. (2014) in Tanzania who discovered that the exposure of mothers to the radio has significant positive impacts on complementary feeding to infants aged 6-23 months. Victor et al. (2014) informed that mothers who have limitations to access the media have a higher probability to not provide complementary feeding in accordance with the WHO recommendation.

The birth cohort of mothers provides significant impacts to the provision of complementary feeding to children aged 6-23 months with negative direction. It means that mothers who were born in the birth cohort of 1963-1977 have a lower probability of providing complementary feeding in accordance with the WHO recommendation compared to mothers who were born in the birth cohort of 1988-1997. Mothers who were born in a younger birth cohort possibly have better education and knowledge compared to mothers who were born in an older birth cohort.

\section{Conclusion}

The age at first marriage has a statistically significant impact on the behaviour of providing nutrition to the first child aged 0-23 months. The age at first marriage positively affects the provision of complementary feeding in accordance with the recommendation of WHO. A higher education may improve one's knowledge, while adequate knowledge will improve awareness to the activity of providing nutrition to children. Therefore, women who married for the first time at an older age and with higher education have a higher probability to provide complementary feeding in accordance with the WHO recommendation.

Different results were found for exclusive breastfeeding to children aged 0-5 months or continued breastfeeding to children after the age of six months. Women who married for the first time at an older age have a lower probability of providing exclusive breastfeeding and continued breastfeeding. This may be due to their higher education level is not followed by adequate knowledge and understanding on breastfeeding activity. Webb, Horton and Katz (2005) argued that the formal school is one of the important sources to obtain knowledge on nutrition. Therefore, health education needs 
to be taught at formal schools, commencing at a young age, so that a girl may have knowledge about health, even if she dropped out from school (Azeze \& Huang, 2014).

Women who married for the first time at an older age have a lower probability with regard to breastfeeding activity, which may also be associated to the issue of human capital. The first marriage at an older age and with better education causes women to have higher human capital, so that the opportunity cost of breastfeeding activity becomes larger. In fact, a portion of women consider that breastfeeding is a painful, difficult and time consuming activity. This was, among others, informed by Avishai (2012) who also stated that the success of breastfeeding needs large funding and resources. Therefore, it is important to make breastfeeding a simple, inexpensive, and pleasant activity that is not time consuming.

\section{References}

Avishai, Orit. (2012, May 17). Breastfeeding is intuitive and easy? No! CNN. Retrieved from https://edition.cnn.com/2012/05/17/opinion/avishai-breastfeeding-women/index.html

Azeze, A.A, \& Huang, W.C. (2014). Maternal education, linkages and child nutrition in the long and short-run: Evidence from the Ethiopia Demographic and Health Surveys. International Journal of African Development, 1(2), 5-28.

Badan Pusat Statistik-BPS (Statistics Indonesia), National Population and Family Planning Board (BKKBN), Kementerian Kesehatan (Kemenkes-MOH), \& ICF International. (2013). Indonesia demographic and health survey 2012. Jakarta, Indonesia: Authors.

Becker, G.S. (1973). A theory of marriage: Part I. Journal of Political Economy, 81(4), 813-846.

Bongaarts, J. (1983). The proximate determinants of natural marital fertility. In R.A. Bulatao \& R.D. Lee (Eds.), Determinants of fertility in developing countries: A summary of knowledge, Part $A$ (pp. 85-114). Washington, D.C.: National Academy Press.

Briawan, D. (2004). Pengaruh promosi susu formula terhadap pergeseran penggunaan air susu ibu (ASI). Individual Essay of Doctoral Program, Graduate School Program of Bogor Agricultural Institute (IPB). Retrieved from http://www.rudyct.com/PPS702-ipb/09145/ dodik_briawan.pdf

Cornall, D. (2011). A review of the breastfeeding literature relevant to osteopathic practice. International Journal of Osteopathic Medicine, 14(2), 61-66. https://doi.org/10.1016/j. ijosm.2010.12.003

Dhakal, S., Lee, T.H., \& Nam, E.W. (2017). Exclusive breastfeeding practice and its association among mothers of under 5 children in Kwango District, DR Congo. International Journal of Environmental Research and Public Health, 14(5), 455. https://doi.org/10.3390/ ijerph14050455

Dubois, L., \& Girard, M. (2003). Social inequalities in infant feeding during the first year of life: The Longitudinal Study of Child Development in Québec (LSCDQ 1998-2002). Public Health Nutrition, 6(8), 773-783. https://doi.org/10.1079/PHN2003497

Freedman, D.A. (2009). Statistical models: Theory and practice. New York, NY: Cambridge University Press.

Graff, H.J. (1979). Literacy, education, and fertility, past and present: A critical review. Population and Development Review, 5(1), 105-140. https://doi.org/10.2307/1972320

Gupta, A. (2006). Infant and young child feeding: An 'optimal' approach. Economic and Political Weekly, 41(34), 3666-3671.

Hamilton, A.E., \& Lewis, M. (2014). Exclusive breastfeeding and breastfeeding in newspapers: Analysis of frames, content, and valence. Proceedings of the New York State Communication 
Association, 2013, Article 5. Retrieved from https://docs.rwu.edu/nyscaproceedings/ vol2013/iss2013/5

Hoddinott, J., Alderman, H., Behrman, J.R., Haddad, L., \& Horton, S. (2013). The economic rationale for investing in stunting reduction. Maternal \& Child Nutrition, 9(S2), 69-82. https:// doi.org/10.1111/mcn.12080

Jones, G.W. (2001). Which Indonesian women marry youngest, and why?. Journal of Southeast Asian Studies, 32(1), 67-78. https://doi.org/10.1017/\$0022463401000029

Jones, G.W., \& Gubhaju, B. (2008). Trends in age at marriage in the provinces of Indonesia (Asia Research Institute, Working Paper No. 105). Singapore: Asia Research Institute. https://doi. org/10.2139/ssrn.1317127

Kumwenda, C., Hemsworth, J., Phuka, J., Arimond, M., Ashorn, U., Maleta, K., ... \& Dewey, K.G. (2015). Factors associated with breast milk intake among 9-10-month-old Malawian infants. Maternal \& Child Nutrition, 12(4), 778-789. https://doi.org/10.1111/mcn.12199

Kusumawati, D.A. (2014). Korelasi faktor sosio demografi dengan pelaksanaan pemberian asi eksklusif di Kabupaten Kudus. Jurnal IImu Keperawatan dan Kebidanan, 5(2). Retrieved from http://ejr.stikesmuhkudus.ac.id/index.php/jikk/article/view/229.

Leroy, J.L., Ruel, M., Habicht, J.P., \& Frongillo, E.A. (2014). Linear growth deficit continues to accumulate beyond the first 1000 days in low- and middle-income countries: Global evidence from 51 national surveys. The Journal of Nutrition, 144(9), 1460-1466. https://doi. org/10.3945/jn.114.191981

Lestariningsih, S. (2016). Hubungan antara umur kawin pertama dan otonomi perempuan dalam rumah tangga di Indonesia (Relationship between first age of marriage and women's household autonomy in Indonesia). Thesis, Magister of Population and Labor Studies, Universitas Indonesia.

Loiselle, C.G., Semenic, S.E., Côté, B., Lapointe, M., \& Gendron, R. (2001). Impressions of breastfeeding information and support among first-time mothers within a multiethnic community. Canadian Journal of Nursing Research Archive, 33(3). Retrieved from http://cjnr. archive.mcgill.ca/article/view/1646

Martino, S.C., Collins, R.L., \& Ellickson, P.L. (2004). Substance use and early marriage. Journal of Marriage and Family, 66(1), 244-257. https://doi.org/10.1111/j.0022-2445.2004.00018.x

McDonald, P. (2013). Societal foundations for explaining fertility: Gender equity. Demographic Research, 28(Article 34), 981-994. https://doi.org/10.4054/DemRes.2013.28.34

Müller, O., \& Krawinkel, M. (2005). Malnutrition and health in developing countries. CMAJ, 173(3), 279-286. https://doi.org/10.1503/cmaj.050342

Naanyu, V. (2008). Young mothers, first time parenthood and exclusive breastfeeding in Kenya. African Journal of Reproductive Health, 12(3), 125-137.

Nguyen, H.T. (2014). Birth weight and growth during the first two years of life: A study in urban and rural Vietnam (Doctoral dissertation, Nordic School of Public Health NHV Göteborg, Sweden). Retrieved from http://urn.kb.se/resolve?urn=urn\%3Anbn\%3Ase\%3Anorden\%3 Aorg\%3Adiva-3607

Odom, E.C., Li, R., Scanlon, K.S., Perrine, C.G., \& Grummer-Strawn, L. (2014). Association of family and health care provider opinion on infant feeding with mother's breastfeeding decision. Journal of the Academy of Nutrition and Dietetics, 114(8), 1203-1207. https://doi. org/10.1016/j.jand.2013.08.001

Prendergast, A.J., \& Humphrey, J.H. (2014). The stunting syndrome in developing countries. Paediatrics and International Child Health, 34(4), 250-265. https://doi.org/10.1179/2046905 514Y.0000000158

Prüss-Üstün, A., Bos, R., Gore, F., \& Bartram, J. (2008). Safer water, better health: Costs, benefits and sustainability of interventions to protect and promote health. Geneva, Switzerland: World Health Organization. Retrieved from http://www.who.int/iris/handle/10665/43840 
Radwan. (2013). Patterns and determinants of breastfeeding and complementary feeding practices of Emirati mothers in the United Arab Emirates. BMC Public Health, 13(1): 171. https://doi.org/10.1186/1471-2458-13-171

Restyani, A. (2001). Pemodelan selang kelahiran anak pertama (Doctoral dissertation, Graduate School Program of Bogor Agricultural Institute (IPB)). Retrieved from http://repository.ipb. ac.id/handle/123456789/12884

Rippeyoung, P.L.F. \& Noonan, M.C. (2012). Is breastfeeding truly cost free? Income consequences of breastfeeding for women. American Sociological Review, 77(2), 244-267. https://doi. org/10.1177\%2F0003122411435477

Roche, M.L., Gyorkos, T.W., Blouin, B., Marquis, G.S., Sarsoza, J., \& Kuhnlein, H.V. (2017). Infant and young child feeding practices and stunting in two highland provinces in Ecuador. Maternal \& Child Nutrition, 13(2), e12324. https://doi.org/10.1111/mcn.12324

Romdoniah, R. (2016). Menikah sekarang atau nanti: Analisis pengaruh usia menikah pertama terhadap status sosial ekonomi (Marry now or later: Influence of first age of marriage on social economic status). Thesis, Faculty of Economics and Business, Universitas Indonesia.

Smith, L.C., Ramakrishnan, U., Ndiaye, A., Haddad, L., \& Martorell, R. (2003). The importance of women's status for child nutrition in developing countries. Washington, D.C.: International Food Policy Research Institute (Department of International Health, Emory University).

Stolzer, J. (2005). Breastfeeding in the 21st century: A theoretical perspective. International Journal of Sociology of the Family, 31(1), 39-55.

Sukamdi, Yuarsi, S.E., \& Tamtiari, W. (1995). Tingkat, pola dan determinan usia kawin wanita dan pria. Populasi, 6(2), 55-77.

UNDP. (2014). Human Development Report 2014, Sustaining Human Progress: Reducing Vulnerabilities and Building Resilience. New York: PBM Graphics. hdr.undp.org/sites/default/ files/hdr14-report-en-1.pdf

UNICEF. (1998). The state of the world's children 1998. Oxford and New York: Oxford University Press.

Victor, R., Baines, S.K., Agho, K.E., \& Dibley, M.J. (2014). Factors associated with inappropriate complementary feeding practices among children aged 6-23 months in Tanzania. Maternal \& Child Nutrition, 10(4), 545-561. https://doi.org/10.1111/j.1740-8709.2012.00435.x

Walker, J.A. (2012). Early marriage in Africa - trends, harmful effects and interventions. African Journal of Reproductive Health, 16(2), 231-240.

Webb, K.E., Horton, N.J., \& Katz, D.L. (2005). Parental IQ and cognitive development of malnourished Indonesian children. European Journal of Clinical Nutrition, 59(4), 618-620. https://doi.org/10.1038/sj.ejcn.1602103

World Health Organization. (2003a). Guiding principles for complementary feeding of the breastfed child. Retrieved from http://www.who.int/nutrition/publications/guiding_ principles_compfeeding_breastfed.pdf

World Health Organization. (2003b). The global strategy for infant and young child feeding. Retrieved from http://www.who.int/nutrition/publications/infantfeeding/9241562218/en/

World Health Organization. (2010). Indicators for assessing infant and young child feeding practices, Part 2 Measurement. Retrieved from http://www.who.int/nutrition/publications/ infantfeeding/9789241599290/en/

Yuniarti, S., Sukandar, H., \& Susiarno, H. (2013). Analisis faktor yang berhubungan dengan fertilitas: Suatu kajian literatur. University of Padjadjaran. Retrieved from http://repository. unpad.ac.id/id/eprint/16404 